\title{
Cost Estimates for Medicines and Laboratory Investigations for Tehsil Headquarter Hospitals of Punjab
}

\author{
Naqvi Hamad, Muhammad Khan Ranjha, Zahida Sarwar
}

\section{ABSTRACT}

INTRODUCTION: Medicine budget allocation in health facilities usually focus on past funding levels and the efficiency of health services delivery. Despite the level of allocation to hospitals, there is a growing gap between available and required medicine budget because the health needs have not diminished. This gap has led us for medicine consumption costing of tehsil headquarters hospitals of Punjab.

OBJECTIVE: To assess average medicine cost including laboratory investigations for indoor and outdoor patient treated at tehsil headquarter hospital of Punjab, working under Punjab Primary and Secondary Healthcare Department.

SETTING: The cost of medicines consumption is estimated both for inpatient as well as outpatients of tehsil headquarter hospitals of Punjab.

METHODOLOGY: Ten tehsil headquarter (THQ) hospitals were selected out of 129 THQ hospitals of Punjab through simple random sampling technique; 2 indoor and 2 outdoor patients were again chosen through simple random sampling technique from each ward of selected THQs and free medicine were dispensed to these selected patients.Cross sectional study design is used and cost of medicine consumption is observed from the patients of randomly selected sample hospitals at single point time or time interval.

RESULTS: This study provides an estimated medicine cost for treating all indoor and outdoor patients at all THQ hospitals under Primary and Secondary Healthcare Department of Punjab. The average cost per outpatient visit is estimated as Rs. 172.46 and the average cost per admission for inpatient care is Rs. 2992.50.Total medicines consumption estimated cost for 129 tehsil headquarter hospitals is Rs 7.18 billion.

CONCLUSION: The current study identified gap between allocated medicines budget and actual medicines needed by the patients. In future this study may provide guidelines to policy maker while calculating actual justified budget allocation for medicines, diagnostic and other supplies to fulfill the patient's requirement effectively and efficiently.

KEY WORDS: Medicine Consumption; Tehsil Headquarter Hospitals; Outdoor Patients; Indoor patients

This article may be cited as: Hamad N, Ranjha MK, Sarwar Z. Cost Estimates for Medicines and Laboratory Investigations for Tehsil Headquarter Hospitals of Punjab. J Liaquat Uni Med Health Sci. 2017;16(03):171-5. doi: 10.22442/jlumhs.171630528

\section{INTRODUCTION}

Medicines are used to prevent and cure disease, to improve or maintain health, and to avoid exacerbations of existing conditions. Evidences have shown that not taking or skipping medicine can adversely affect the trajectory of a disease, thus impacting the total cost of treatment and care. It is estimated that for every 1 percent increase in medicine utilization, total Medicare program costs fall by 0.2 percent $^{1}$. Successful treatment of disease requires consistent use of the medicines but due to poverty, patients skip dose. Non adherence to medicines is a major healthcare cost and quality problem and evidences show that it is directly related to poor clinical outcomes and high healthcare costs ${ }^{2}$. Medicine consumption cost is direly needed by managers and policy makers for making decisions about how to improve efficiency, effectiveness, quality and enhance sustainability. This would be helpful for making cost projections, budgeting, and evidence based decision making. Many researchers such as Chatterjee et al, Sara Collins, Mycka et al, and Bertsimaset $\mathrm{al}^{3-7}$ worked on healthcare cost including medicine. As per census 2017, population of the Punjab province is around 110,012,442 with average growth of 2.13. Punjab government is focusing to provide free medicine to all patients attending the public health facilities. Punjab population density has increased to 490 persons per square kilometer ${ }^{8}$ and accordingly disease burden has also been increased. Punjab province comprises of 36 districts and 140 tehsils and Punjab government has put in place an elaborate and extensive network of health facilities in 
both rural and urban areas. In Punjab, 129 Tehsil Headquarter level Hospitals (THQs) are providing outpatient and inpatient care. Each THQ hospital is serving a population of 0.5 to 1.0 million. It provides promotive, preventive, curative, diagnostics, inpatient, referral services and also specialized care.

District Health Information System about tehsil headquarters hospitals of Punjab show rising trend of inpatient and outpatient visits in 2015-16 as compared to $2014-15^{9}$. The demand for healthcare by the public as outpatient has increased by $25.2 \%$ in $2015-16$ as compared to year 2014-15 and inpatient visits have been increased by $22.5 \%$ and this increasing trend shows that this will grow much more in coming years. In current study, medicine consumption cost of out-door and indoor patients including laboratory \& diagnostics tests cost has been estimated for all tehsil headquarter (THQ) hospitals of Punjab, under Primary and Secondary Healthcare Department (P\&SHD) of Punjab, after providing free medicines to the outdoor and indoor patients.

This study would be helpful to policy makers for the allocation of appropriate budget according to patient's load of the particular hospitals of Punjab so that trajectory of disease and Health Medicare cost may be reduced.

\section{METHODOLOGY}

In literature, cost studies exist for different levels of health care services and providers but are either specific to a particular disease or based on a specialty. No comprehensive study has been carried out in district headquarter hospitals to calculate the medicine consumption costs of the hospitals.

This study provides an estimated cost of medicine consumption per patient at tehsil headquarter level hospitals of Punjab on the basis of outpatient and inpatient data. Study is conducted in two parts, first we estimated the average cost of medicine dispensed to patients in each ward then we estimated unit medicine cost for outpatient and inpatient from the record of inpatient and outpatient data of period July 2015 to June 2016 obtained from district health information system. Primary information is used in first part and secondary information in second part. Cross sectional study design is used and cost of medicine consumption is observed from the patients of $10 \mathrm{THQ}$ hospitals which are selected through simple random sampling technique at single point in time or time interval. Study location is $10 \mathrm{THQ}$ hospitals situated in different districts of Punjab, Pakistan and sample study was conducted from September-December 2016. Two-stage sampling technique is used in this study. In first stage 10 THQs were selected through simple random process and in second stage 2 indoor and 2 outdoor patients were selected from each ward through simple random process. Hospital administration was directed to dispense hundred percent free medicines to these selected patients. For outpatients, medicine was given for three days and average medicine cost on that basis is estimated whereas inpatient medicine cost was estimated from date of admission to date of discharge. Prices of dispensed medicines were collected from Punjab government medicine central rate contract and locally purchased medicines from the market. For reducing error, this exercised was done in $10 \mathrm{THQ}$ hospitals and repeated in two different months of year to get reliable results. List of randomly selected Tehsil headquarter hospitals is; 1) THQ Chishtian 2) THQ Ahmadpur East 3) THQ Talagang 4) THQ Kamoke 5) THQ Wazirabad 6) THQ Pind Dadun Khan 7) THQ Mian Channu 8) THQ Taunsa 9) THQ Bhalwal, 10) THQ. Mailsi.

Sampled patients have been provided with hundred percent free medicines. Average medicine cost per patient for each indoor and outdoor specialty / ward is obtained. Average market prices of X-Ray \& laboratory investigations (complete blood count, basic metabolic panel, and comprehensive metabolic panel), Urine Examination and viral markers (Anti Hepatitis C Virus, Australia Antigen Hepatitis-B Surface Antigen and HIV AIDS) are also estimated. Cost for medicines and diagnostics consumption is calculated on the basis of pricesof central rate contract and local purchase prices whichever applicable. Medicine cost is the cost to treat patients but this cost can be influenced by changes in the price of medical products and services

Average cost of medicine is calculated for inpatient care and outpatient specialties, like medical ward, surgical ward, pediatrics ward, OB/GYN, eye ward, ENT ward, orthopedics, cardiology ward, psychiatry ward, others, dental ward, TB/chest ward, skin ward, general OPD, emergency / casualty, homeo case, Tibb / Unani shifakhana and others. Cost of radiology (X-Ray) and other laboratory investigations is also assessed.

\section{RESULTS}

Price list of medicine of Government central rate contract for purchasing drugs and medical supplies for its healthcare facilities has been used and in case of non-availability of medicine, local market prices have been used. Medicine was provided to outdoor patients (OPD) for three days and medicine provided to inpatients from date of patient admission to date of 
discharge was considered. These patients were given free medicine for treating illness. Average medicine cost estimate per outdoor patient and per inpatient in different wards was calculated as shown in Table I, whereas average market price of X-Ray and laboratory investigation is determined through discussion with specialist, visit and meetings with concerned personnel.

The data regarding the total number of indoor and outdoor patients treated in all THQ hospitals for all specialties has been collected from District Health Information System ${ }^{9}$. Hospitals perform a range of different functions, including provision of inpatient treatment services within various medical specialties and general outpatient care services. There is variation in outdoor and inpatient care costs depending upon prices of different medicines and length of stay. Total indoor and outdoor patients for each specialty observed in THQ hospitals are multiplied by average indoor / outdoor specialty medicine cost. Similar procedure is adopted for number of $X$-rays and other laboratory investigations to estimate laboratory cost as shown in Table 2. Estimated indoor medicine cost without laboratory charges for the period of July 2015 to June 2016 is around Rs 3.9 billion and estimated outdoor medicine cost for the same period is Rs. 2.9 billion.

Estimations are made according to the number of visits in outpatient department and number of admissions in inpatient departments. Outpatient cost is estimated on three days medicine distribution and inpatient cost is estimated from date of admission to date of discharge. Average outdoor patient unit cost is calculated by dividing total estimated outdoor cost by total outdoor patients for the same year and same procedure is adapted to calculate average indoor patient unit cost. The average cost per outpatient visit is estimated as Rs. 172.46 and the average cost per admission for inpatient care is Rs. 2992.50. Unit diagnostic cost is Rs. 126.04. Total estimated medicine cost is 7.18 billion and total indoor and outdoor patients for year 2015-16 were 18.09 million. Unit medicine cost for outdoor patient is Rs. 172.46 and unit medicine cost for indoor patient is Rs. 2992.5. Unit laboratory investigation cost including X-Rays per patient is Rs. 126.04 as shown in Table III.

Punjab health system is basically a hospital dominated system that is why largest share of public sector health expenditure is for hospitals. For the year 2015-16 the total annual medicine cost for all THQ Hospitals under primary and secondary healthcare department obtained from PIFRA is approximately Rs.87 million and estimated cost of medicine consumption for free treatment of all patients who visited THQ hospitals (data taken from DHIS) during that period is Rs. 7.18 billion. The gap between existed and estimated medicine consumption cost is Rs. 6.3 billion.Projected increase in medicine cost for outdoor and inpatient department is given in Table IV which suggests an increase in medicine budget of government THQ hospitals of Punjab. The availability, quality and utilization rate of drug increases by theincrease in the budget for drugs and medical supplies and this, in turn decreases total cost per admission.Following previous trend, the projected outdoor cost is calculated on $25.2 \%$ increase from total outdoor patients of 2015-16 and projected indoor cost is calculated on $22.5 \%$ increase from total indoor patients. Future projected cost is shown in Table IV.

TABLE I: AVERAGE COST ESTIMATE FOR OUTPATIENT, INPATIENT WARDS \& DIAGNOSTICS

\begin{tabular}{|c|c|c|c|}
\hline $\begin{array}{c}\text { Wards I } \\
\text { Specialties }\end{array}$ & $\begin{array}{c}\text { Average } \\
\text { medicine } \\
\text { cost (PKR) } \\
\text { per OPD } \\
\text { visit with } \\
3 \text { days } \\
\text { medicine }\end{array}$ & $\begin{array}{l}\text { Average Indoor } \\
\text { medicine cost } \\
\text { (PKR) per } \\
\text { patient from } \\
\text { hospital } \\
\text { admission to } \\
\text { discharge }\end{array}$ & $\begin{array}{c}\text { Average lab } \\
\text { investigation } \\
\text { Cost }\end{array}$ \\
\hline Medical Ward & 250 & 2,675 & - \\
\hline Surgical Ward & 300 & 2,700 & - \\
\hline Pediatrics Ward & 215 & 3,490 & - \\
\hline OB/GYN & 335 & 4,500 & - \\
\hline Eye Ward & 95 & 1,250 & - \\
\hline ENT Ward & 90 & 780 & - \\
\hline Orthopedics & 310 & 4,000 & - \\
\hline Cardiology Ward & 275 & 1,750 & - \\
\hline Psychiatry Ward & 95 & 500 & - \\
\hline TB/Chest ward & - & 410 & - \\
\hline Others & 100 & 1500 & - \\
\hline Dental & 175 & - & - \\
\hline Skin & 250 & - & - \\
\hline General OPD & 85 & - & - \\
\hline $\begin{array}{l}\text { Emergency / } \\
\text { Casualty }\end{array}$ & 250 & - & - \\
\hline Homeo Case & 55 & - & - \\
\hline $\begin{array}{l}\text { Tibb / Unani } \\
\text { ShifaKhana }\end{array}$ & 35 & - & - \\
\hline $\begin{array}{l}\text { Lab investigations } \\
\text { (excluding } \\
\text { X-Rays) }\end{array}$ & - & - & 110 \\
\hline X-Rays & - & - & 175 \\
\hline
\end{tabular}


Cost Estimates for Medicines and Laboratory Investigations

\section{TABLE II: SPECIALTY-WISE INDOOR / OUTDOOR PATIENTS COST + LABORATORY INVESTIGATION} COST IN 129 THQ HOSPITALS

\begin{tabular}{|c|c|c|c|c|c|c|c|}
\hline Specialty & $\begin{array}{l}\text { Outdoor } \\
\text { Patients }\end{array}$ & $\begin{array}{l}\text { Est. Outdoor } \\
\text { medicine Cost } \\
\text { (PKR) }\end{array}$ & $\begin{array}{l}\text { Indoor } \\
\text { Patients }\end{array}$ & $\begin{array}{c}\text { Average } \\
\text { Length of } \\
\text { Stay } \\
\text { (Days) }\end{array}$ & $\begin{array}{c}\text { Est. Indoor medicine } \\
\text { Cost (PKR) }\end{array}$ & $\begin{array}{c}\text { \# of Lab. } \\
\text { Investigations }\end{array}$ & $\begin{array}{c}\text { Est. } \\
\text { Investigation } \\
\text { Cost }\end{array}$ \\
\hline Medical Ward & 1152609 & $@ 250=88152250$ & 472459 & 4.2 & @2675=1263827825 & - & - \\
\hline Surgical Ward & 606647 & $@ 300=81994100$ & 158862 & 5.8 & $@ 2700=28927400$ & - & - \\
\hline Pediatrics & 1735817 & @215 = 73200655 & 280095 & 4 & $@ 3490=77531550$ & - & - \\
\hline OB/GYN & 1348965 & @335 =451903275 & 206154 & 6.3 & $@ 4500=927693000$ & - & - \\
\hline Eye Ward & 811422 & $@ 95=77085090$ & 18189 & 1.5 & @1250 =22736250 & - & - \\
\hline ENT Ward & 137734 & $@ 90=12396060$ & 3456 & 4 & $@ 780=2695680$ & - & - \\
\hline Orthopedics & 236797 & $@ 310=73407070$ & 13177 & 5.1 & $@ 4000=52708000$ & - & - \\
\hline Cardiology Ward & 93951 & $@ 275=25836525$ & 6110 & 4.7 & $@ 1750=10692500$ & - & - \\
\hline Psychiatry Ward & 7380 & $@ 95=701100$ & 3 & 1 & $@ 500=1500$ & - & - \\
\hline TB/Chest & - & _ & 93 & 3.9 & $@ 410=38130$ & - & - \\
\hline Others & 750567 & $@ 100=75056700$ & 147234 & 1.6 & $@ 1500=220851000$ & - & - \\
\hline Dental Ward & 631708 & @175 = 10548900 & - & - & - & - & - \\
\hline Skin Ward & 92279 & $@ 250=23069750$ & - & - & - & - & - \\
\hline General OPD & 5657685 & $@ 85=480903225$ & - & - & - & - & - \\
\hline Emergency/Casualty & 2740697 & @250 = 85174250 & - & - & - & - & - \\
\hline Homeo & 432720 & $@ 55=23799600$ & - & - & - & - & - \\
\hline Tibb/Unani Shifa & 353172 & $@ 35=12361020$ & - & - & - & - & - \\
\hline X-Rays & - & - & - & - & - & 746881 & $\begin{array}{r}@ 175= \\
130704175\end{array}$ \\
\hline $\begin{array}{l}\text { Other Lab } \\
\text { investigations }\end{array}$ & - & - & - & - & - & 2279044 & $\begin{array}{r}@ 110= \\
250694840\end{array}$ \\
\hline Total & $16,790,150$ & $2,895,589,570$ & $1,305,832$ & & $3,907,702,835$ & $3,025,925$ & $381,399,015$ \\
\hline
\end{tabular}

TABLE III: UNIT PATIENT COST

\begin{tabular}{|c|c|c|c|c|c|c|}
\hline Health Facility & Outdoor Patients & $\begin{array}{c}\text { Unit Medicine } \\
\text { Cost of Outdoor } \\
\text { Patient for 3 days }\end{array}$ & $\begin{array}{c}\text { Indoor } \\
\text { Patients }\end{array}$ & $\begin{array}{c}\text { Unit Cost of Indoor Patient } \\
\text { from date of admission to } \\
\text { date of discharge }\end{array}$ & $\begin{array}{c}\text { Lab. } \\
\text { Investigations }\end{array}$ & $\begin{array}{c}\text { Unit } \\
\text { Investigation } \\
\text { Cost }\end{array}$ \\
\hline THQ & $16,790,150$ & 172.46 & $1,305,832$ & 2992.50 & $3,025,925$ & 126.04 \\
\hline
\end{tabular}

\section{TABLE IV: PROJECTED OUTDOOR \& INDOOR COST FOR NEXT YEAR}

\begin{tabular}{|c|c|c|c|c|c|c|}
\hline $\begin{array}{c}\text { Health } \\
\text { Facility }\end{array}$ & $\begin{array}{c}\text { Total OPDs } \\
\text { from July 2015 } \\
\text { to June 2016 }\end{array}$ & $\begin{array}{c}\text { Projected OPD } \\
\text { Increase for } \\
\text { next year on the } \\
\text { basis of Trend }\end{array}$ & $\begin{array}{c}\text { Projected } \\
\text { OPD } \\
\text { medicine } \\
\text { Cost }\end{array}$ & $\begin{array}{c}\text { Total Indoors from } \\
\text { July 2015 to June 2016 }\end{array}$ & $\begin{array}{c}\text { Projected Indoor } \\
\text { Patient increase } \\
\text { for next year on } \\
\text { the basis of Trend }\end{array}$ & $\begin{array}{c}\text { Projected } \\
\text { Indoor } \\
\text { medicine } \\
\text { Cost }\end{array}$ \\
\hline $\mathrm{THQ}$ & $16,790,150$ & $21,021,267$ & $3,625,327,707$ & $1,305,832$ & $1,599,644$ & $4,786,934,670$ \\
\hline
\end{tabular}

Projected OPD medicine cost for the year 2016-17 is around Rs. 3.6 billion whereas projected indoor medicine cost for the year $2016-17$ is Rs. 4.8 billion. 


\section{DISCUSSION}

The importance of provision of healthcare and health services by the government cannot be underestimated. This is important specially to reduce the suffering of those who are below poverty line and in turn would decrease the out of pocket expenditure by the poor community. Poor and marginalized people always have high expectation from government regarding healthcare and in this scenario, it is governments responsibility to provide free of cost medicine to those who cannot afford medical expenses. However Public sector healthcare system is inadequate and under funded. These poor conditions in the health sector may be attributed to a number of factors like poverty, unequal access to health facilities, and inadequate allocation for health, high population growth and infant mortality. The reality is that most of tehsil level hospitals are not currently providing health care services up to the desired level, owing to multiple factors like large patient influx, scarcity of resources, human resource deficiency and non-functional equipment, poor medicine dispensation etc. The Government of Punjab is now undertaking many initiatives at its tehsil level hospitals through improved access, quality and equity in health services.Increasing trend of outdoor and indoor patients of last four years shows the confidence of people on Government health facilities.

\section{CONCLUSION}

The cost estimates suggest that the medicine budget of THQ hospitals of Punjab should be revisited as the gap between existing medicine consumption cost and estimated medicine cost is around Rs.6.3 billion. Existing medicine budget of Punjab is obtained from Project to Improve Financial Reporting and Auditing (PIFRA) Punjab. This estimated annual medicine consumption cost is much needed for hospital because if there are lapses in drug supplies then patient has to skip medicine due to non-affordability or purchase out of pocket to ensure a complete treatment. A continuous, reliable supply of drugs is a sine qua non for quality care and reducedburden of disease.

\section{RECOMMENDATION}

Keeping in view and considering the ground realities, it is the need of the hour to allocate more money for medicine purpose because THQ hospitals are providing service delivery to a larger population of Punjab. Hospital administration can also provide free medicine to needful by their resources through health councils or by some other means to resolve medicine gap at local level. Punjab government should take more measures like stress on filling vacant posts of doctors, monitoring mechanism, proper medicine dispensability etc. Effectiveness may be measured in terms of improvements in health status on a long term basis.

\section{ACKNOWLEDGEMENT}

The authors are grateful to the editor and referees for their constructive comments, which have led to substantial improvements in manuscript.

\section{REFERENCES}

1. Congressional Budget Office, USA. Offsetting effects of prescription drug use on Medicare's spending for medical services (Report). November 29, 2012. Available from: https://www.cbo.gov/ publication/43741.

2. Osterberg $\mathrm{L}$, Blaschke $\mathrm{T}$. Adherence to Medication. N Engl J Med. 2005; 353: 487-497.

3. Chatterjee S, Levin C, Laxminarayan R. Unit Cost of Medical Services at Different Hospitals in India. Plos One 2013; 8(7):e69728.

4. Collins S, Radley D, Schoen C, Beutel S. State trends in the cost of employer health insurance coverage, 2003-2013. Issue brief (Commonwealth Fund). 2014; 32:1-9.

5. Malik MA, Gul W, Iqbal SP, Abrejo F. Cost of primary health care in Pakistan. J Ayub Med Coll Abbottabad 2015; 27(1): 88-92.

6. Mycka JM, Dellamano R, Kolassa EM, Wonder M, Ghosh S, Hay J, et al. Good research practices for measuring drug costs in cost effectiveness analyses: an industry perspective: the ISPOR Drug cost Task force Report -Part V. Value Health. 2010; 13(1): 25-27.

7. Bertsimas D, Bjarnadóttir M, Kane MA, Kryder JC, Pandey R, Vempala $S$, et al. Algorithmic prediction of health-care costs. Operations Research 2008; 56(6):1382-1392.

8. Ministry of Finance (Govt. of Pakistan). Pakistan Economic Survey; 2015-16. Available from: http:// www.finance.gov.pk/survey_1516.html

9. Health Dept. Punjab (Govt. of Punjab, Pakistan): District Health Information System in Punjab (DHIS). Available from: http:// health.punjab.gov.pk/DHIS

\section{AUTHOR AFFILIATION: \\ Naqvi Hamad \\ Policy and Strategic Planning Unit \\ Muhammad Khan Ranjha \\ Policy and Strategic Planning Unit \\ Health Department, Government of Punjab. Health Department, Government of Punjab. Email: naqvihamad@hotmail.com \\ Zahida Sarwar \\ Policy and Strategic Planning Unit Health Department, Government of Punjab.}

